\title{
SYNOPSES
}

\section{SOME THOUGHTS ON PENSION SCHEME DESIGN}

\author{
BY P. N. THORNTON
}

(Synopsis of a paper presented to the Society on 18 November 1986)

THE paper covers three main aspects of occupational pension scheme design:

- how to design a scheme;

-existing designs, their shortcomings and their virtues;

-new designs for the future.

It was originally sparked off by the apparent polarization of debate on pension scheme design into 'Money Purchase' and 'Final Salary' planes. Apart from the lack of attention given to the 'Career Average Revalued Earnings' design for occupational schemes, might there not be new designs to meet the changing demands of society?

The paper first examines the employer's objectives in establishing a scheme and the employees' requirements from a scheme. There is an apparent conflict between the different concepts of 'providing for members' needs', providing 'a reward for services' and enabling employees to 'identify with their pension assets' and the pension scheme designer has to attempt to resolve this.

A comparison of the relative attractions of final salary and money purchase designs then leads to the conclusion, amongst others, that a combination of both types is attractive. The features of hybrid final salary/money purchase schemes, where the value of final salary benefits on the normal scale are underpinned by a money purchase minimum based on the accumulation of members' contributions and part of the employer's contribution, are then examined, although it is noted that the potential costs could be significant.

The paper then moves on to consider the Career Average Revalued Earnings design of scheme, where each year's benefit accrual is revalued to retirement according to a chosen index. It is suggested that such schemes have advantages over other designs, particularly for manual workers, part-timers, and early leavers. It is also noted that the way in which each year's accrual is defined can readily be amended if necessary in such schemes, which makes them very flexible. The scope for choosing different bases for the revaluation is examined, and the suitability of this design for industry-wide schemes noted.

The paper concludes with a review of some outmoded scheme designs which might be worth bringing up to date for current requirements, and a round up of the aspects of scheme design of most concern to employers at the time of writing. These include equal treatment of men and women, retirement ages, and the effect 
on schemes of members opting out, or in, under the choices to be given to them in April 1988.

In the paper it is suggested that whilst it is for employers to take decisions on pension scheme design, actuaries have an important role to play in encouraging their clients to review and improve the design of the schemes.

\title{
A LOOK AT EQUITY, BONUSES AND PROFITS USING AN OB PROFITABILITY MODEL
}

\author{
By H. D. White, F.I.A.
}

(Synopsis of a paper presented to the Society on 20 January 1987)

THE paper used modern profitability testing techniques to put a recently maturing with-profit policy under the microscope. The author asked some provocative questions about traditional actuarial practice.

In the first place he demonstrated the need for a high level of equity backing in order to justify current with-profit performance. He then went on to discuss the incidence of equity investment. He demonstrated the pooled interest approach does not give good results as it is distinctly advantageous to invest completely in equities at the commencement of a policy and only move into fixed interests investments closer to maturity. Despite the recent bull market this would have produced maturity values $20 \%$ better than those obtainable under a traditional pooled interest approach. Pooling gives a slow build-up of assets in early years.

Given that most offices now have high equity backing current bonus structures were questioned. The author suggested the nature of the assets justifies a high level of final bonus and a slow build-up of reversionary bonus with a low rate of bonus on sum assured. The paper pointed out that if investment conditions deteriorated existing business and particularly short-term policies would currently be guaranteeing an unjustifiably high level of existing reversionary bonus. This would give rise to inequitable losses and impose restraints on future investment policy and performance.

Other assumptions that affected profitability such as taxation, expenses and surrenders were considered. The most financially important of these were the surrender rates and surrender basis. Historically surrender rates have been lower than at present, but surrender bases were profitable and built up profits for survivors. Due to increased reversionary bonuses current surrender values are now much higher and give cause for concern. These could lead to poor performance and an uncompetitive life insurance industry in the future.

The paper concluded that offices had pursued an appropriate high equity investment policy, but were behind the times with their reversionary bonus policies. Too high levels of reversionary bonuses were giving too generous 